\title{
The Relationship Between Religion and Law from the Perspective of Functionalism and Ideology
}

\author{
Xuan Dong ${ }^{1 * \#}$ Chenyu Yang ${ }^{2 \#}$ Kun Zhang $^{2}$ Shan Jiang ${ }^{3}$ Xiao Cai $^{2}$
}

\author{
${ }^{1}$ School of Foreign Languages, Heilongjiang University, Harbin, Heilongjiang 150080, China \\ ${ }^{2}$ School of Law, Heilongjiang University, Harbin, Heilongjiang 150080, China \\ ${ }^{3}$ Faculty of Western Languages, Heilongjiang University, Harbin, Heilongjiang 150080, China \\ *Corresponding author. " These authors contributed equally to this work. \\ Email:2004154@hlju.edu.cn; zhangkunfighter@yeah.net
}

\begin{abstract}
Religion and law are both civilized phenomena when human society develops to a certain stage. During this time, religion and law have come into existence. There is a strong association in retroaction to society between religion and law in both ideological and functional aspects. This paper is to explore the relationship between religion and law considering in functional and ideological prospective, so that the two can play the role of integration, governance, cohesion in the field of their respective regulation.
\end{abstract}

Keywords: religion, law, function, legal ideology, relevance

\section{INTRODUCTION}

\subsection{The Functional Relevance of Law and Religion Has an Embodiment in the Complementary Function}

The law adjusts people's behavior by compulsory norm and solidifies the social structure to enhance its stability by means of rules. The law itself regulates society by the guarantee of its ruling power, however, its mandatory principle and forcible order ignores the feeling of social group in humanistic and psychological level. Over-upright legal regulation and simple pursuit for objective justice will inevitably lead to the rule being away from social emotion, easily forming the exclusive rule of tyranny, which is not conducive to the development of the social function of law [1]. However, the holiness and detachment of religion determine the flexibility of its control means. In the process of its regulation, the purpose of social control is mostly achieved in an invisible and non-compulsory way. Religion focuses more on the control of people's inner emotions, which seems extremely weak but there are few obstacles in the phase of its implementation [2]. It is to instruct people's behavior pattern through the spiritual power of belief. Compared with the law, it lacks enforcement force and guarantee of institutional order. But it has more effective control in guiding people's behavior and uniting social forces, which can be seen that the two have innate complementarity in social integration.

Due to the regionalism and nationality of Chinese culture, it forms the diversity of culture. Social regulation has been a tough philosophy for the ruling class since ancient times. During the spring and autumn period, different academic schools emerged, among which the legalist ideology was unique in terms of social governance. At the end of the warring states period, legalism was greatly promoted in the Qin dynasty, which was the first to complete the unification. It had a stabilizing effect on the society at the beginning of the implementation while its coercive tool contributed to the anti-social psychology of the social groups. The legal source of "law comes from the king" causes the king to be above the law and cannot be recognized in the psychology of the ruled class.The rule of the Qin dynasty applied the law blindly, roughly and arbitrarily, completely regarding it as an instrument. During that time, it advocates the rule of law Rather than the rule of rites originated from the law of religious sacrifice. Once the law lacks the support of belief and denies the complementarity of law together with religion in function, it will eventually perish in the social outcry. The Han dynasty was enlightened by the experience and lessons of the previous dynasties, and the law absorbed the guiding ideology of the Huang-Lao school of "making people recuperate and multiply", which means after a long period of turmoil, there is an urgent need to shore up the people and revive the economy, and the religious Confucianism of Dong Zhongshu's "correspondence between man and heaven". These two ideologies respectively rationalized the construction of legal system for feudal ruling class from the viewpoint of human psychology and religious ethics. These two ideologies respectively rationalized the construction of legal system for feudal ruling class from the viewpoint of human psychology and religious ethics. The ruling class can rely on the religious legal and ethical form to carry out more discourse power and basis of governance. Compared with the cold and rigid rule, the ruling class must have more confidence and goodwill towards this kind of rule which is filled with human kindnes. And the longer the time, the deeper the dependence. As far as social stability is concerned, this kind of complementary way of maintaining stability between religion and law is more trustworthy. If the legal concept and religious spirit permeate each other, the ruling 
class will to some extent abide by its own laws under the psychological pressure of "harmony between human being and nature" and "punishment of god", even though such laws are made for its rule. The complementary function of religion and law is supposed to realize the regulation of the whole society, so as to achieve the purpose of promoting social development.

\subsection{The Functional Relevance of Law and Religion Has a Reflection in the Functional Identity}

From the perspective of their functional characteristics, both law and religion are inevitably infected with political color when they are used as means of social regulation. Although the starting point of law and religion is not the same when they come into being, they both show clear political characteristics when they are applied to the concepts of social adjustment and control. This shows that the characteristics of law and religion are identical when used for the same purpose.

From the perspective of their functional objects, as a kind of ideology, religion has human beings as its functional object. Religious classics and fundamental theories are about the ultimate meaning of human beings. The spiritual significance of religion lies in the exploration of self-consciousness and the analysis of the essence of self-feeling from the fantasy of the unknown. From the viewpoint of the existence of life, this paper expounds the final destination of human beings [3]. The practical significance of religion is reflected in two aspects, on the one hand, in the function of psychological adjustment, "religion can provide people with a sense of security and some comfort, so that they can eliminate psychological anxiety and fear". [4] modern medical research shows that religious activities contain a lot of psychological hints, which can promote the secretion of body hormones and play a role of physiological regulation. On the other hand, it is reflected in the function of personality cultivation. Religion makes people awe and restrain the desire which is not advocated by religion, so as to regulate people's behavior [5]. Religious belief itself is closely related to moral ethics. Religion can play the same function as ethics in the cultivation of personality. According to pound's social law school, the object of legal function is also human. "law can't command the nature without consciousness, it can only aim at the same kind of people as the maker" [6] the guidance of law to people and people's behavior is to restrict the object of observation by making law. Although they are different in content and way, they are same in the function of law in regulating people. It shows that both law and religion are devoted to the study of human beings and their behaviors.

The complementarity and identity of the functions of religion and law have a certain operability to the construction of legal functions in the legal system of today's society. Even if there is a natural contradiction between religion and law, it is not irreconcilable in certain aspects of its function.

\section{THE IDEOLOGICAL CONNECTION BETWEEN RELIGION AND LAW}

The important sign that human beings are different from other creatures in the nature is that human beings produce ideology-act beyond the reflection level of nature and physiological conditions through the cognition of self and the world. This paradigm refined by information content is ideology. Both religion and law are the crystallization of human spiritual civilization and the ideological system that confirms the existence of human society [7]. There are many relations between them in the content and the constitution of ideology.

\subsection{Relevance Between Religion and Legal Ideology}

Because of its rationality, some ideas in religion have been popularized into the universal concept in long-term social practice, which has a recessive guiding role in the establishment of various social rules. And some religious laws and basic principles have become the basic principles of law. In Buddhism, the concept of harmony and equality mean that all things in the world are spiritual and all things are equal. The religious concept of equality is demonstrated from the perspective of the existence of life. The principle of equality is one of the basic legal principles in law. Although the object category of the principle of equality in law is more precise than that in religion, it is essentially homogeneous.Taoist nature is an ecological ethical ideology of practical significance. It is proposed that human beings should find a suitable position in the nature and adapt to the nature, so as to continue the survival and development of human beings. "The relationship between man and nature is regarded as a relationship regulated and restricted by ethical principles" [8] this idea is in the same line with the principle of coordinated development in environmental law. The core of this principle is based on sustainable development and emphasizes the sustainability of environmental ecological utilization. We should conform to the objective law and live in harmony with nature. This reflects the relationship between religion and law in the view of nature.

Christianity was very popular in the Middle Ages in Western Europe, which had a lasting influence on the western legal system. The authority ideology is absorbed by law. The Christian code of conduct is established by canon, and the authority of Canon comes from the sacredness of God. As a kind of social behavior standard, law also needs authority to ensure the implementation of law, which comes from the state's compulsory force. Religion and law are interlinked in the ideology of ensuring the continuity of their lives and the validity of norms.

In religion, there are often superstitious concepts such as cause and effect, reincarnation, past life and present life, all of which convey the same pattern, that is, behavior result responsibility. In the reincarnation of Buddhism, evil is the result of evil, which embodies the discipline of religion, good is the result of good, which embodies the guidance and 
restraint of religion. In addition to some differences in the definition of the time of the effect of the result and the way of bearing, this kind of ideology and the ideology of bearing responsibility in law are basically the same in the mode. The guiding and evaluating function of law is also based on this ideology.

\subsection{The Relationship Between Religion and Legal Ideology}

Both religious ideology and legal ideology are guided by philosophy. From the perspective of religious sociology, religious ideology is an empirical variable. Religious ideology is not constant from beginning to end. In order to maintain its vigorous vitality, religion will change with the change of social form and mode. From a philosophical point of view, this is the embodiment of materialistic dialectics and the driving force for the development of things. As an ideological and cultural phenomenon, religion can last for such a long time. It can exist in different regions, different historical backgrounds and different cultural environments, and play a significant role and have a profound impact. It is just benefited from the guidance of Philosophy in religion. law is the product of rational spirit. Self-production has the incomparable advanced nature of other ideology. Keeping pace with the times is also an important characteristic of legal ideology [9].

Religion and law are the unity of generality and particularity. Since ancient times, religion and law have produced many schools, which have different academic views and ideologies. However, there is a consensus on the issue of universal ideology and public knowledge [10]. For example, Christianity can be roughly divided into Catholic Church and Orthodox Church, which both believe that the Lord is the only true God, although they have different forms of church and different understandings of priesthood. In Buddhism, there are some differences in the idea of practice and the ideology of achievement, but the ideology of the ultimate destination of life is the same. Different schools of law have different application of penalty ideology and different division of rights and obligations. However, we have the same understanding of the basic principles of the law that have reached consensus. From the philosophical basis and characteristics of their ideological composition, it shows the relevance of religion and law in ideological composition.

\section{CONCLUSION}

Religious and legal images span two curves in the coordinate system of human civilization. They are contradictory and consistent in many aspects, such as value tendency, truth belief, procedure content, etc., and there are interlaced parts that are difficult to be clarified. The direct consequence of the absence of religious tradition is the neglect of the function of religion in the development of law. Through the analysis of the function and ideological basis of law and religion, it shows the connection between the ideological basis and function of religion and law, and as the most ultimate relevance, it is a representational basis for the mutual transplantation of the power of religious belief and the value of legal rationality. When we study the abnormal phenomena of religion and law, such as disenchantment and return to disenchantment, the two kinds of correlation are also the breakthrough to solve such difficult problems.

\section{ACKNOWLEDGMENT}

This work was supported by New Think-tank Research Project of Heilongjiang Province (19ZK004), and National Students' Training Program for Innovation and Entrepreneurship (201910212038).

\section{REFERENCES}

[1] Kathryn A. Heard. Theorizing Employment Division v. Smith: The Affective Politics of the Legal Regulation of Religion.2020,16(1):53-69.DOI:10.1177/1743872116678 213.

[2] Alan G. Nixon. 'Non-Religion' as Part of the 'Religion' Category in International Human Rights. 2020, 11(2).DOI:10.3390/rel11020079.

[3] Cohen. On Liberalism's Religion[J]. Critical Review of International Social and Political Philosophy,2020,23(1).DOI:10.1080/13698230.2018.148 7233.

[4] Yang Heli. The significance of religion in human society and religious freedom [n]. China Nationalities daily, August 28, 2012.

[5] Susan Hayward,Iselin Frydenlund. Religion, Secularism, and the Pursuit of Peace in Myanmar[J]. The Review of Faith \& International Affairs,2019,17(4).DOI:10.1080/15570274.2019.168176 5.

[6] Yang Chunfu. On the object of law and the law of objectification [J]. Journal of Nanjing University, 1997, (01): 25 .

[7] Religion and Law[J]. Religious Studies Review,2019,45(3).DOI:10.1111/rsr.14147.

[8] Qing Xitai. Taoist ecological ethics and its practical significance $[\mathrm{J}]$. Journal of Sichuan University, 2002, (01): 28.

[9] James Dingemans. International Law and Religion: Historical and Contemporary Perspectives. 2019, 21(3):366-367.DOI:10.1017/S0956618X19000577. 
[10] Caroline K. Roberts. Freedom of Religion or Belief:

An International Law Commentary . By Heiner

Bielefeldt, Nazila Ghanea, and Michael Wiener .

Oxford : Oxford University Press , 2016 . Pp. v +660.

Hardback, £125.00/\$210.00.[J]. Religious Studies

Review,2017,43(3).DOI:10.1111/rsr.13092. 